\title{
A Defesa no Inquérito Policial
}

\author{
Rafael Francisco Marcondes de Moraes
}

\section{INTRODUÇão}

O direito de defesa deve ser entendido tanto sob uma ótica individual, como prerrogativa do acusado de reagir a uma imputação que lhe seja formulada, quanto sob um prisma de direito público, como garantia necessária da pessoa imputada e da própria sociedade, para a legítima aplicação da lei penal em um Estado Democrático de Direito. ${ }^{2}$

Desse modo, para o pleno desempenho do direito de defesa, a imputação criminal, vale dizer, a atribuição a alguém da prática de uma determinada infração penal, deve ser extensivamente considerada, abrangendo não apenas a acusação formal (denúncia ou queixa-crime), que precede o início da etapa judicial da persecução, mas também a apuração estatal na fase extrajudicial, de modo a assegurar meios de atuação e uma reação defensiva à pessoa investigada pelo envolvimento em um fato delituoso. Logo, o sujeito suspeito deve ser entendido como "imputado" em sentido amplo, viabilizando o exercício de seu direito de defesa. ${ }^{3}$

1 Mestrando pela Faculdade de Direito da Universidade de São Paulo-USP. Especialista em Direito. Professor concursado da Academia da Polícia Civil do Estado de São Paulo. Palestrante e docente em cursos jurídicos e universidades. Autor de livros e artigos jurídicos. Delegado de Polícia do Estado de São Paulo.

2 FERNANDES, Antônio Scarance. Reação defensiva à imputação. São Paulo: Revista dos Tribunais, 2002, p. 29.

3 FERNANDES, Antônio Scarance. Reação defensiva...cit., p.123. 
Como defendia o professor Sérgio Marcos de Moraes Pitombo ${ }^{4}$, acentuada parcela da doutrina processualista penal ainda insiste no equívoco de considerar a investigação criminal materializada no inquérito policial uma peça meramente informativa, desprezando ou ignorando com isso o fato de que o procedimento legal investigatório ganha em eficiência com a regular cooperação do exercício do direito de defesa, de maneira que o suspeito e o indiciado não podem ser tratados como objetos ou sujeitos estranhos à etapa extrajudicial da persecução penal.

O aludido sofisma doutrinário se revela na afirmação infundada e reducionista de que não existe direito de defesa na investigação criminal e em especial na sua instrumentalização legal representada no inquérito policial.

Para se constatar o patente erro na referida assertiva, basta mencionar a possibilidade do indiciado de exercer no interrogatório policial sua autodefesa positiva (oferecendo sua versão dos fatos), ou negativa (usando seu direito ao silêncio), e ainda pleitear assistência advocatícia (defesa técnica), ou postular diligências e juntada de documentos (CPP, art. 14), sem prejuízo da defesa exógena via medidas judiciais como o habeas corpus e o mandado de segurança. ${ }^{5}$

De igual sorte, o magistério de Joaquim Canuto Mendes de Almeida já veiculava inferência nesse sentido: ${ }^{6}$

Asseverar que o indiciado nenhum interesse tem a defender no inquérito policial é desconhecer que o Delegado de Polícia, tanto quanto o Juiz Criminal, subordinado ao princípio de

4 PITOMBO, Sérgio Marcos de Moraes. Inquérito policial: exercício do direito de defesa. Boletim IBCCRIM - Instituto Brasileiro de Ciências Criminais. Ano 7, Edição Especial, no 83 , out.1999, p.14.

5 LOPES JR., Aury Lopes. Direito processual penal. São Paulo: Saraiva, 2015, p.170.

6 ALMEIDA, Joaquim Canuto Mendes. O direito de defesa no inquérito policial. Revista da Faculdade de Direito da Universidade de São Paulo, v. 52. São Paulo: USP, 1957, p.113. 
legalidade, é instrumento da lei, obrigado a cumprir a norma penal, em seu bifrontismo, tanto sob o aspecto do interesse de punir, que é de todos os indivíduos impessoalmente considerados, quanto sob o aspecto do interesse de não punir, fora das limitações derivadas da norma penal, que é pessoalmente do indiciado.

\section{Devido PROCesso Legal, CONTRAditório e AMPLA DEFESA}

A garantia ou princípio do devido processo legal está assegurada no inciso LIV do artigo $5^{\underline{0}}$ da Constituição Federal: "ninguém será privado da liberdade ou de seus bens sem o devido processo legal", enquanto os princípios do contraditório e da ampla defesa encontram previsão no inciso seguinte (LV): "aos litigantes, em processo judicial ou administrativo, e aos acusados em geral, são assegurados o contraditório e a ampla defesa, com os meios e recursos a ela inerentes".

Do ponto de vista científico, a norma do devido processo legal é uma cláusula geral, composta por termos vagos ou indeterminados e cujas consequências também são indeterminadas. Por conta dessa indeterminação é que, ao longo da história, o conceito tem se amoldado e evoluído, sem nunca se esvaziar. Dele são extraídos praticamente todos os princípios processuais como o contraditório, a ampla defesa, a proibição de provas ilícitas e a motivação das decisões. O devido processo legal serve para qualquer atuação do Estado, seja ela administrativa, legislativa ou jurisdicional.

O princípio do contraditório, por sua vez, como desdobramento do devido processo, apresenta-se em duas dimensões: a formal e a substancial. Na acepção formal, significa o direito que a todos assiste de participar de processo que lhe diga respeito ou afete seu interesse (direito à participação). Sob o aspecto 
substancial, cuida do direito de influenciar no conteúdo da decisão estatal, do poder de influência, de pleitear a produção de provas e de expor versões e argumentos. Logo, o que se designa princípio da ampla defesa nada mais é do que a dimensão substancial do contraditório. ${ }^{7}$

Observa-se que os três princípios têm incidência conjunta e integrada. $\mathrm{O}$ devido processo abrange a observância dos procedimentos previstos em lei, ou seja, do caminho, do rito legal, para que seja impelida responsabilização criminal ao indivíduo transgressor. Tal caminho deve se desenvolver com ampla defesa, compreendida pela conjugação da autodefesa (defesa pessoal) e da defesa técnica (realizada pelo defensor com capacitação jurídica), e com contraditório, identificado pelo binômio ciência e participação.

Ainda que a aplicação integral dos princípios em tela seja vislumbrada no âmbito judicial, momento em que vigora por completo o chamado sistema acusatório, no qual há evidente distribuição das funções de acusar, defender e julgar a órgãos distintos, é inegável que, diante da nova ordem constitucional, houve forte flexibilização e reformulação do denominado sistema inquisitivo, sob o enfoque que este concentraria num mesmo agente estatal os papéis de acusador, defensor e julgador, e que seria o vigente na etapa preliminar de investigação criminal.

Nesse contexto, projetando a garantia do devido processo para a etapa preliminar e extrajudicial da persecução penal, concebe-se uma devida investigação legal, melhor comentada em tópico posterior neste trabalho.

7 DIDIER JR., Fredie. Curso de direito processual civil. Salvador: Jus Podivm, 2012, p.57. 


\section{INQUÉRITO POLICIAL: ESCORÇO HISTÓRICO E ATIVIDADE DE POLÍCIA JUdiciáRIA}

Para a compreensão do alcance do direito de defesa na etapa preliminar do processo penal, forçoso traçar um sucinto panorama hodierno e uma compatibilização constitucional da investigação criminal no Brasil.

Nessa conjuntura, a ordem jurídica instituída pela Constituição Federal promulgada em 1988 exigiu e continua exigindo uma releitura do papel de todas as instituições públicas brasileiras, de modo a se ajustarem e se harmonizarem com os postulados e comandos irradiados da Lei Maior, sobretudo considerando que a legislação infraconstitucional, mormente no campo criminal e processual criminal, permaneceu regida em sua estrutura fundante pelo Código Penal (Decreto-lei no 2.848/1940) e pelo Código de Processo Penal (Decreto-lei no 3.689/1941), diplomas oriundos de momento político e histórico ditatorial e defasado em face da visão garantista reclamada pela Carta Magna.

A base processual penal representa um termômetro do grau de autoritarismo ou de democracia da Constituição de um país. ${ }^{8} \mathrm{O}$ processo penal reflete diretamente a forma como o Poder Público soberano dialoga com os cidadãos: um processo penal autoritário é sinônimo de um Estado autoritário. Já um processo penal garantista, regido por direitos e garantias individuais, espelha um Estado liberal e democrático, visto que as orientações políticas determinam a concepção estrutural do processo penal. ${ }^{9}$

8 GOLDSCHMIDT, James. Principios generales del proceso: problemas jurídicos y políticos del proceso penal. vol. II. Buenos Aires: Ediciones Jurídicas Europa-América, 1961. p. 72.

9 QUEIROZ, David. Delegado de Polícia, o primeiro garantidor de direitos fundamentais! Mas quem garante os direitos do garantidor? Empório do Direito, 02 jul. 2015. 
Com efeito, a aplicação da sanção penal, o denominado jus puniendi, exclusividade do Poder Público, pressupõe a adequada apuração dos fatos que se amoldam às infrações penais, tarefa essa atribuída às instituições de polícia judiciária (Polícias Civis dos Estados da Federação e Polícia Federal no âmbito da União), na exata dicção dos parágrafos $1^{\circ}$ e $4^{\circ}$, do artigo 144, da Constituição Federal de 1988. Referidos órgãos públicos estão incumbidos de investigar e reprimir as infrações penais, consubstanciadas nas condutas eleitas como reprováveis e atentatórias aos bens jurídicos mais relevantes.

A atividade de polícia judiciária é definida como aquela que atua depois de ocorrida a infração penal, após frustrada a prevenção delitiva pelas corporações de policiamento ostensivo, e realiza a investigação criminal por intermédio de inquérito policial ou de termo circunstanciado, para determinar a comprovação do delito (materialidade) e sua respectiva autoria, destinando-se à justa responsabilização penal. ${ }^{10}$

Na exegese constitucional, como bem enfatiza Ives Gandra da Silva Martins ${ }^{11}$, a densidade ôntica da polícia judiciária a revela como sendo a polícia do Poder Judiciário, que o auxilia na reta preparação da demanda penal ao executar e legitimar a etapa extrajudicial do processo penal.

10 ANGERAMI, Alberto e PENTEADO FILHO, Nestor Sampaio. Direito administrativo sistematizado, 2008, p. 85. Adota-se a nomenclatura "polícia judiciária" na sua acepção genuína, traduzida na Súmula $\mathrm{n}^{\mathrm{0}}$ 1, do I Seminário Integrado da Polícia Judiciária da União e do Estado de São Paulo-Repercussões da Lei 12.830/13 na Investigação Criminal: "A expressão "polícia judiciária" designa o complexo de atividades exercidas pelas Polícias Civil e Federal, tendentes à apuração de autoria, materialidade e demais circunstâncias das infrações penais comuns, à execução do policiamento preventivo especializado e ao desempenho de funções típicas de auxílio amplo à prestação jurisdicional penal, sempre sob direção e responsabilidade do Delegado de Polícia".

11 MARTINS, Ives Gandra da Silva. Prefácio. In: PEREIRA, Eliomar da Silva; DEZAN, Sandro Lucio (Coord.). Investigação criminal conduzida por Delegado de Polícia: comentários à Lei 12.830/2013. Curitiba: Juruá, 2013, p.16. 
Essencial ponderar que o Poder Judiciário é o destinatário imediato dos subsídios angariados na investigação criminal, de modo que a Autoridade Judicial exerce constante controle de legalidade do acervo de elementos de convicção coligido, filtro legalista afeto, sobretudo, à preservação de garantias individuais ${ }^{12}$, e que deve perdurar mesmo após o encerramento do inquérito policial, por intermédio de um juízo de admissibilidade da pretensão acusatória inicial formulada, seja pelo órgão ministerial nas ações públicas seja pelo particular nas ações penais privadas ou subsidiárias das públicas. ${ }^{13} \mathrm{~A}$ acusação e a defesa devem figurar como destinatários mediatos do trabalho investigativo criminal, porquanto se valem do lastro informativo amealhado no inquérito policial (do qual também podem e devem participar instando e fornecendo dados relevantes às instituições de polícia judiciária) para a elaboração de suas respectivas teses.

Não há como negar que a atuação estatal na seara criminal deve começar com atividades eminentemente preventivas, no intuito de evitar o cometimento de delitos. ${ }^{14}$ Fracassada a

$12 \mathrm{O}$ controle judicial da investigação criminal se opera tanto no encerramento do inquérito policial, cujo relatório final elaborado pelo Delegado de Polícia presidente tem como destinatário o Juiz de Direito competente (CPP, art. $\left.10, \S 1^{\underline{0}}\right)$, quanto no curso do procedimento investigatório legal e em todas as representações por medidas cautelares sujeitas à reserva de jurisdição (CPP, arts.13, IV e 282, § 2º), e ainda no fornecimento de todas as informações necessárias à instrução e julgamento dos processos judiciais (CPP, art. 13, I).

13 Destaca-se que a resposta preliminar à inicial acusatória disciplinada no artigo 396A do Código de Processo Penal, acrescido pela Lei Federal no 11.719/2008, reforça a necessidade de sadio controle judicial via juízo de admissibilidade da pretensão constante na inicial acusatória, oferecendo oportunidade para a defesa arguir preliminares e argumentar tudo que lhe interesse no debate, inclusive para obstar o recebimento da acusação, dispositivo consentâneo a uma busca de equilíbrio e paridade de armas entre as partes e a uma devida investigação criminal, imparcial e desvinculada de orientações acusatórias ou defensivas, compromissada com a apuração autêntica e garantista dos fatos.

14 A prevenção criminal compreende o policiamento ostensivo e a manutenção da ordem pública, por intermédio da presença, da fiscalização e do patrulhamento preventivo estatal, missão que a Carta Magna atribui para a Polícia Federal na prevenção ao tráfico de drogas, ao contrabando e ao descaminho e nas funções de polícia marítima, aeroportuária e de fronteiras (CF, art. 144, § 1丷, II e III), para a Polícia Rodoviária 
prevenção criminal, seja pela ineficiência ou insuficiência no patrulhamento ostensivo pelos órgãos de polícia administrativa ou pela ausência de outras formas de controle, inicia-se a persecução penal, em regra por meio do inquérito policial, instrumento que reúne os atos e trabalhos voltados para a apuração do fato aparentemente criminoso. ${ }^{15}$ Caso sejam angariados elementos para tanto, subsidia a ação penal para que o agente infrator seja responsabilizado por sua conduta nos termos da lei. Do mesmo modo, impede processos judiciais indevidos contra cidadãos inocentes, afastando imputações injustas ou suspeitas infundadas. ${ }^{16}$

Sob um enfoque funcional, em apertada síntese, o EstadoInvestigador (exercido pelos órgãos de polícia judiciária - Polícia Civil e Polícia Federal) apura os fatos concretos observados no meio social, formalizando e coligindo no inquérito policial os elementos que obtiver nessa atividade, submetendo o expediente ao Estado-Julgador (incumbência do Poder Judiciário), que irá decidir de acordo com as provocações e ponderações consignadas tanto pelo Estado-Acusador ou pela parte a ele equivalente (papel do ofendido nas ações penais privadas e do Ministério Público nas ações penais públicas) quanto pelo Estado-Defensor ou pela parte que cumpra esse mister (função realizada pela Defensoria Pública ou pelo Advogado constituído pelo investigado).

Federal nas rodovias federais $\left(\mathrm{CF}\right.$, art. $\left.144, \S 2^{\circ}\right)$, para a Polícia Ferroviária Federal nas ferrovias federais (CF, art. 144, $\left.\S 3^{\circ}\right)$, para as Guardas Municipais nos bens, serviços e instalações municipais (CF, art. 144, § $8^{\circ}$ e Lei Federal no 13.022/2014) e para as Polícias Militares na esfera estadual (CF, art. 144, $\S 5^{\circ}$ ).

15 Vale ressaltar que a divisão entre as atividades de polícia administrativa (prevenção criminal) e polícia judiciária (investigação criminal) costuma ser apontada como sendo de origem francesa, razão pela qual se diz que o trabalho da polícia judiciária começa no ponto onde termina o trabalho da polícia administrativa. KEEDY, Edwin. The preliminary investigation of crime in France. University of Pennsylvania Law Review, v. 88, n. 4, February, 1940, p.407.

16 ZACCARIOTTO, José Pedro. A polícia judiciária no estado democrático. Sorocaba: Brazilian Books, 2005, p. 213. 
Portanto, é na primeira etapa dessa dinâmica que se insere o inquérito policial, procedimento legal incorporador da investigação criminal e que, como regra, inaugura o exercício do poder-dever punitivo estatal.

O inquérito policial hoje deve funcionar como um filtro garantista ${ }^{17}$, assegurador de uma intervenção estatal harmônica aos direitos fundamentais, de modo a viabilizar a persecução penal plena nos casos necessários e fundados e, acima de tudo, impedir injustiças e repressões inúteis, arbitrárias ou precipitadas, revelando-se como verdadeiro instrumento de promoção de justiça criminal ao conciliar as garantias individuais da pessoa investigada com o direito à segurança da coletividade.

Sob o prisma jurídico, o inquérito policial, como adiantado, compreende o procedimento que formaliza o conjunto de meios e providências adotados e destinados a apurar as circunstâncias que envolvem o fato criminoso, revelando os elementos que comprovem sua ocorrência e que evidenciem sua materialidade e, da mesma maneira, identificando a pessoa ou as pessoas responsáveis pelo cometimento da infração, ou seja, esclarecendo a autoria delitiva.

Outrossim, ao centralizar a corporificação da investigação criminal no inquérito policial, a liberdade investigativa estatal é reduzida a limites mais estritos, de modo a não admitir ilegítimas iniciativas investigativas fora do âmbito do procedimento previsto em lei, propiciando um modelo de investigação mais transparente e, por isso, objetável quando não alinhado às garantias individuais do investigado. ${ }^{18}$

17 TRINDADE, Daniel Messias da. O garantismo penal e a atividade de polícia judiciária, 2012, p. 20.

18 BARBOSA, Emerson Silva. O devido processo penal e as garantias do contraditório e da ampla defesa no inquérito policial. Sistema penal \& violência. Revista da Faculdade de Direito da Pontifícia Universidade Católica do Rio Grande do Sul. Porto Alegre, 2011, p.78. 
A doutrina remonta a origem da expressão "inquérito policial" na legislação brasileira ao Decreto no 4.824, de 22 de novembro de 1871, regulamentador da Lei no 2.033, de 20 de setembro do mesmo ano. O texto do aludido decreto assim definia em seu artigo 42: “O inquérito policial consiste em todas diligências necessárias para o descobrimento dos fatos criminosos, de suas circunstâncias e de seus autores e cúmplices, devendo ser reduzido a instrumento escrito" ${ }^{\prime 1}{ }^{19}$

Na legislação vigente, o artigo $4^{\circ}$, caput, do Código Processo Penal - Decreto-lei nº 3.689/1941, assenta que a polícia judiciária terá por fim a "apuração das infrações penais e da sua autoria" e,

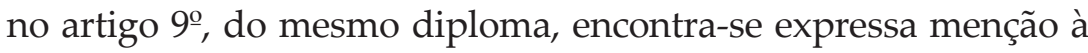
nomenclatura "inquérito policial", também identificado e previsto

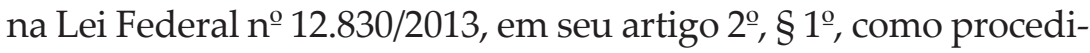
mento "que tem como objetivo a apuração das circunstâncias, da materialidade e da autoria das infrações penais", por meio do qual o Delegado de Polícia conduz a investigação criminal.

De fato, por intermédio do inquérito policial busca-se realizar um diagnóstico para se estabelecer o que possivelmente ocorreu, consistindo, como regra, em uma retrospectiva, ou seja, em uma tarefa voltada para o passado, que procura idealizar e reconstruir o fato investigado, analisando todos os elementos que com ele possuam algum vínculo.

Essa reconstrução é considerada a busca da "verdade", cuja faceta garantista corresponde à "verdade possível", "atingível" ou "probabilidade qualificada" ${ }^{20}$, e tem por escopo tentar revelar o que efetivamente ocorreu dentro do que for possível aferir, esgotando-se todos os recursos lícitos disponíveis.

19 MORAES, Bismael Batista de. Direito e Polícia: uma introdução à polícia judiciária. São Paulo: Revista dos Tribunais, 1986, p. 129.

20 MOURA, Maria Tereza Rocha de Assis. A prova por indícios no processo penal. Rio de Janeiro: Lumen Juris, 2009, p. 104. 
Não por outra razão, ensina Marco Antônio Desgualdo: ${ }^{21}$

Só entendemos como investigação verdadeira aquela que se sustente sobre o tripé Ciência, Lógica e Legalidade. A Lógica serve-se da Ciência para se instrumentalizar e a observância à legalidade é simples decorrência do trabalho técnico de apuração. O resultado desse labor transparece, por força da Semiótica, em linguagem formalizada, na essência do inquérito policial (que, despido de formalismos, se subordina unicamente ao rito da Lógica). Este possui vida própria, pois conta uma história. A história de um crime.

A reconstituição dessa "história" norteia todo o trabalho policial investigativo, concretizado no inquérito policial, sempre sustentado nas três bases consignadas: o respaldo legal de suas intervenções e atividades, a utilização e constante atualização dos recursos científicos e tecnológicos, em todas as áreas de conhecimento humano, e o escorreito exercício do raciocínio lógico para suas conclusões.

Diante da atual perspectiva constitucional do processo penal, similar à postura do Juiz de Direito na demanda judicial e, guardadas as devidas proporções, espera-se uma posição imparcial e estritamente profissional do Delegado de Polícia na condução das investigações. A grande diferença encontra-se no fato de que, diverso da Autoridade Judicial, cuja imparcialidade é como regra passiva, dependendo de provocação dos sujeitos parciais (defesa e acusação), a Autoridade Policial atua de ofício, ativamente, buscando o reto cumprimento da legislação posta que, em última análise, representa a vontade coletiva e a defesa dos interesses da sociedade.

Nessa concepção, a Autoridade Policial deve se ater aos fatos e seus elementos e não isoladamente à pessoa do investigado, numa conjectura do direito penal do fato desde a fase inves-

21 DESGUALDO, Marco Antonio. Recognição visuográfica e a lógica na investigação. São Paulo: Polícia Civil do Estado de São Paulo, 2006, p.19. 
tigativa. O Delegado de Polícia não figura como parte na perquirição criminal, ele busca a verdade atingível dos fatos e, somente por via de consequência, esclarecer a autoria delitiva.

\section{Titularidade, Independência Funcional E imparcialidade do Delegado de Polícia}

A titularidade do inquérito policial é constitucionalmente atribuída ao Delegado de Polícia, sendo a carreira jurídica qualificada pela formação policial responsável por presidir com discricionariedade motivada o procedimento que materializa a investigação criminal (CF, artigo 144, $\S 1^{\circ}$, IV e $\S 4^{\circ}$, Lei Federal nº 9.266/1996,

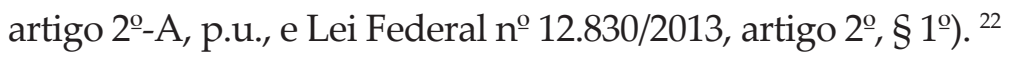

O desempenho profissional da Autoridade Policial exige deliberações sempre fundamentadas, prestigiando o princípio da motivação, com fundamento expresso na Lei Federal $\mathrm{n}^{\mathrm{o}}$ 9.784/1999, artigo $2^{\circ}$ e, no plano estadual paulista, no comando do artigo 111 da Constituição do Estado de São Paulo, direcionado a toda a Administração Pública.

A motivação consiste na fundamentação da decisão, com exposição dos fatos e dos dispositivos legais que a ensejaram, e promove transparência e probidade na gestão da coisa pública, bem como permite que a pessoa interessada conheça as razões de cada manifestação estatal.

O Delegado de Polícia, como representante do Estado e da vontade da lei na direção da polícia judiciária e na presidência do inquérito policial é, portanto, agente público submetido ao referido princípio. Deve a Autoridade Policial fundamentar as deliberações tomadas no curso da investigação criminal, as quais, em regra, são exaradas mediante despachos (autônomos

22 Nesse sentido: STF, ADI no 1570, rel. Min. Maurício Corrêa, DJ 22/10/2004. 
ou no corpo de peças confeccionadas), ou ainda nas conclusões consignadas no relatório final do procedimento investigativo.

A liberdade na convicção obviamente é regrada pelos limites legais, devendo ser motivada estampando-se os fundamentos fáticos e jurídicos que a Autoridade Policial invocou para determiná-la. Como todo operador do direito, é natural que as manifestações do Delegado de Polícia sejam providas de embasamento legal e apoiadas em precedentes doutrinários e jurisprudenciais, para que seus efeitos sejam atendidos e os interessados possam com elas concordar, acatando-as, ou debatê-las, caso vislumbrem entendimento jurídico diverso, desafiando inclusive controle judicial se necessário.

O poder discricionário, ligado à liberdade de decisão diante de um caso concreto, faculta que a autoridade competente opte por uma dentre várias soluções possíveis, todas válidas perante o Direito, de acordo com juízos de oportunidade, conveniência, justiça ou equidade, próprios da autoridade, porque não definidos de modo estanque pelo legislador, pelo contrário, positivados com acentuada flexibilidade, mas que precisam sempre respeitar os limites delineados pela lei, os quais, se ultrapassados, tornam a decisão arbitrária e ilegal. ${ }^{23}$

A discricionariedade no âmbito da direção da atividade de polícia judiciária consiste na denominada independência funcional, e compreende tanto o juízo motivado de oportunidade e conveniência para capitanear as investigações criminais (juízo de prognose), como também, e sobretudo, a liberdade de expressão do pensamento e do entendimento à luz do direito (juízo de diagnose). ${ }^{24}$

23 DI PIETRO, Maria Sylvia Zanella. Direito administrativo, 2003, p. 205.

24 CASTRO, Henrique Hoffmann Monteiro de. Juízos de prognose e diagnose do Delegado são essenciais na investigação. Revista Consultor Jurídico, São Paulo, 9 ago. 2016. Referido autor leciona que, ao formular um juízo de prognose, o Delegado de 
A independência funcional, atrelada a um juízo não vinculado de modo inflexível, permite a adoção de uma medida dentre uma gama de soluções juridicamente aceitáveis, e representa a liberdade de convicção motivada, inerente e conferida à autoridade pública operadora do direito para que exerça suas funções de acordo com o que sua consciência e discernimento reputarem legalmente amparado, adequado e, acima de tudo, justo, guiando-se ainda pelas finalidades da instituição a qual pertence, sem submissão a controle hierárquico no exercício desse mister. ${ }^{25} \mathrm{~A}$ hierarquia existente restringe-se às questões de caráter administrativo, materializada pelo chefe da instituição, mas nunca, como dito, quanto ao aspecto funcional.

O Delegado de Polícia presidente do inquérito policial possui independência funcional em relação à tipificação legal e à sequência com que as diligências são determinadas, ou seja, no juízo prognóstico no tocante à forma de condução e ao rumo das providências investigativas, até porque cada fato apresenta circunstâncias peculiares com muitas variáveis, e a investigação criminal precisa ser dirigida de acordo com a ordem cronológica com que os elementos informativos são obtidos, seguindo também um juízo diagnóstico mediante avaliação técnico-jurídi$\mathrm{ca}^{26}$ e o tirocínio profissional da Autoridade Policial, responsável

Polícia projeta um olhar para frente, em busca da verdade possível dos fatos, e assim opta pelas medidas investigativas mais aptas a descortinar o evento delitivo. Já nas deliberações acerca das classificações jurídicas com base nos elementos amealhados resultantes das investigações desenvolvidas, a Autoridade Policial exerce um juízo de diagnose, cuidando-se de um lançar de olhos para trás, a fim de decidir pela existência ou não de dados acerca da materialidade e da autoria delitiva.

25 LESSA, Marcelo de Lima. A independência funcional do Delegado de Polícia paulista. São Paulo: Adpesp - Associação dos Delegados de Polícia do Estado de São Paulo, 2012, p.4-5.

26 Citam-se como exemplos de juízos de diagnose do Delegado de Polícia as decisões jurídicas motivadas para determinar ou não o indiciamento de um sujeito investigado, incluindo a avaliação para decretar ou não a prisão em flagrante delito de um sujeito apresentado suspeito de prática criminosa, para o enquadramento provisório de fatos noticiados em determinado tipo penal que a Autoridade Policial reputar configurado ou não, entre outras deliberações jurídicas fundamentadas inerentes à presidência da 
pela preservação e produção das provas no momento oportuno e mais eficiente, e atento aos regramentos legais para sua legitimidade e aproveitamento em juízo.

A independência funcional preconiza que a atuação funcional da autoridade pública com ela contemplada não fica ao livre arbítrio desta, pois se sujeita não apenas à sua consciência, mas sempre à Constituição e às leis. Aliás, nesta ordem: Constituição, leis e, por fim, consciência. ${ }^{27}$ Daí porque se exige a respectiva motivação.

Diante desse panorama, a imprescindível liberdade de convicção jurídica na atuação do Delegado de Polícia, intrínseca às suas funções legais, consolidou-se em diversas Cartas Estaduais, como na Constituição Paulista, com a promulgação e entrada em vigor da Emenda Constitucional no 35, de 3 de abril de 2012, a qual alterou o parágrafo 3ํㅜ da Constituição do Estado de São Paulo, e passou a estipular que "aos Delegados de Polícia é assegurada independência funcional pela livre convicção nos atos de polícia judiciária".

A necessária independência funcional aos Delegados de Polícia, hoje justa e expressamente reconhecida na Carta Paulista e na Constituição de outros Estados da Federação ${ }^{28}$,

investigação criminal.

27 SABELLA, Walter Paulo. Independência funcional e ponderação de princípios. Revista Justitia, 2007, p.2-3. Da incidência do princípio da independência funcional sobre o agir do operador do direito decorre a impossibilidade de haver sujeição hierárquica entre os agentes públicos e o chefe da respectiva instituição, exceto no âmbito administrativo, porém sem que a relação hierarquizada se estenda à seara técnico-funcional, impedindo também que esses agentes sejam responsabilizados por equívocos de atuação no estrito exercício de suas funções, salvo hipóteses de culpa grosseira, má-fé ou abuso de poder.

28 No mesmo sentido há também expressos comandos na Constituição do Estado do Espírito Santo (artigo 128, § $6^{\circ}$ ), assim como na Constituição do Estado de Santa Catarina (artigo 106, § 5º), na Constituição do Estado do Amazonas (artigo 115, § $3^{\text {o)}}$ ), na Constituição do Estado do Tocantins (artigo 116, $\S 1^{\circ}$ ), e ainda na Lei Orgânica do Distrito Federal (artigo 119, § $4^{\circ}$ ). 
encontra-se devidamente garantida e conceituada em lei como sendo a "autonomia intelectual para interpretar o ordenamento jurídico e decidir, com imparcialidade e isenção, de modo fundamentado" ${ }^{29}$.

No que tange à imparcialidade do Delegado de Polícia presidente da apuração penal, cumpre frisar o correto entendimento segundo o qual não se aplica o artigo 107 do Código de Processo Penal, no ilógico trecho que prevê não ser possível opor suspeição às Autoridades Policiais, disposição que estaria superada após a Constituição Federal de 1988. ${ }^{30}$

Assim, o procedimento investigatório dirigido por Delegado de Polícia suspeito ou impedido desafia impetração de mandado de segurança ${ }^{31}$, sem prejuízo de que seja antes formulado pedido administrativo ao superior hierárquico para designação motivada de outra Autoridade Policial. ${ }^{32}$

Ressalta-se que a imparcialidade do Delegado de Polícia, mais que um atributo para a legitimidade da investigação criminal, deve ser vista como essencial ao princípio da legalidade e da igualdade do Estado Democrático de Direito, afirmando nela

29 Nos exatos termos do artigo $1^{\circ}, \S 2^{\circ}$, da Lei Complementar Estadual Paulista $n^{\underline{0}}$ 1.152/2011, com a redação estipulada pela Lei Complementar Estadual no 1.249, de 3 de julho de 2014. Referida Lei Complementar no 1.249/2014 também reafirmou a independência funcional e irredutibilidade de vencimentos como garantias da carreira jurídica de Delegado de Polícia (Lei Complementar noำ1.152/2011, art.1ํㅡ, § $1^{\circ}$ ).

30 CABRAL, Bruno Fontenele; SOUZA, Rafael Pinto Marques. Manual prático de polícia judiciária. Salvador: Jus Podivm, 2013, p. 68-69. Referidos autores reputam que o artigo 107 do CPP não teria sido recepcionado pela Constituição Federal, reforçando que, no que se refere ao impedimento da Autoridade Policial, pode ser aplicado, por analogia, a Lei Federal no 9.784/99, que cuida das hipóteses em que a autoridade ou agente público é considerado impedido (arts.18 a 21).

31 SAAD, Marta. O direito de defesa no inquérito policial. São Paulo: Editora Revista dos Tribunais, 2004, p. 370.

32 NUCCI, Guilherme de Souza. Código de processo penal comentado. São Paulo: Editora Revista dos Tribunais, 2011, p. 108. Referido entendimento foi citado em decisão do Tribunal de Justiça do Estado de São Paulo: Ap. 00496575.3/8, 8ª C., $4^{\circ}$ Grupo, rel. Eduardo Braga, j. 24/01/2008, v.u. 
a paridade de armas entre a defesa do investigado e a acusação pública ou privada. Assim, além de direito subjetivo do investigado, o Delegado de Polícia imparcial consiste em garantia de uma justa investigação criminal.

\section{DeVidA INVESTIGAÇÃo LEGAL}

A garantia do devido processo deve ser aplicada e ajustada à etapa preliminar e extrajudicial da persecução penal, de modo a projetar também como garantia fundamental uma devida investigação legal, na lição de Édson Luís Baldan: ${ }^{33}$

Premissa basilar, como acentuado, é que a persecução penal apresenta dois momentos distintos: o da investigação e o da ação penal. Embora dotada de dois instantes, a persecução é, em si, una, indivisível. Daí que a cláusula do devido processo legal (due process of law, ou do giusto processo) deva ungir a ação estatal durante esse todo indivisível. Por esse raciocínio, não só o acusado (na fase judicial) mas também o imputado (na fase preliminar de investigação ou, mesmo, aquém desta) deve gozar, na plenitude, da garantia individual do devido processo legal.

A devida investigação legal, em suma, está estruturada nos seguintes preceitos e princípios configuradores: ${ }^{34}$

$1^{\underline{o})}$ Legalidade: a atividade investigatória deve resultar de autorização emanada de disposição expressa de lei.

$\left.2^{\underline{o}}\right)$ Investigante natural: para que haja a devida investi-

33 BALDAN, Édson Luís. Devida investigação legal como derivação do devido processo legal e como garantia fundamental do imputado. In: KHALED JR., Salah (Coord.). Sistema penal e poder punitivo: estudos em homenagem ao prof. Aury Lopes Jr. Florianópolis: Empório do Direito, 2015, p.165.

34 BALDAN, Édson Luís. Devida investigação legal como derivação do devido processo legal e como garantia fundamental do imputado. In: KHALED JR., Salah (Coord.). Sistema penal e poder punitivo: estudos em homenagem ao prof. Aury Lopes Jr. Florianópolis: Empório do Direito, 2015, p.169-178. 
gação legal, a autoridade presidente da apuração deve ter prévia e expressa atribuição por lei, exegese que se depreende da justaposição do julgador natural da Constituição Federal para a etapa preliminar.

Nesse enfoque, deve se consolidar como princípio o Delegado de Polícia natural, que ora se passa a comentar.

Fala-se em "Juiz natural" como um princípio extraído dos incisos XXXVII e LIII, do artigo 5, da Constituição Federal ${ }^{35}$, segundo o qual é vedada a criação de juízo ou tribunal de exceção.

Como é cediço, deve haver uma autoridade pública predeterminada para legitimamente processar e julgar uma pessoa por um fato específico. Não se admite a submissão discriminatória de uma pessoa a um julgador público que não seja aquele competente também a todos os seus semelhantes.

Nessa esteira, colaciona-se para análise o parágrafo $4^{\circ}$ do artigo $2^{\circ}$ da Lei Federal ํㅜำ 12.830/2013:

O inquérito policial ou outro procedimento previsto em lei em curso somente poderá ser avocado ou redistribuído por superior hierárquico, mediante despacho fundamentado, por motivo de interesse público ou nas hipóteses de inobservância dos procedimentos previstos em regulamento da corporação que prejudique a eficácia da investigação.

Tendo por alusão o princípio do Juiz natural e com arrimo no dispositivo em comento, tem-se defendido o desenvolvimento do princípio do Delegado de Polícia natural ${ }^{36}$, na medida em que se observa a regra de que o inquérito policial ou o termo circunstanciado deverão ser presididos por um Delegado de Polícia

$35 \mathrm{CF}$, art. 5o, incisos XXXVII: "não haverá juízo ou tribunal de exceção", e LIII: "ninguém será processado nem sentenciado senão pela autoridade competente".

36 BARBOSA, Ruchester Marreiros. Delegado natural é princípio basilar da devida investigação criminal. Revista Consultor Jurídico, 6 out. 2015. 
previamente definido, segundo critérios objetivos (normalmente territoriais ou por matéria), somente excepcionada mediante avocação ou redistribuição do procedimento investigatório por superior hierárquico, ainda assim via despacho fundamentado ou no interesse público ou na inobservância de procedimentos disciplinados em ato normativo da instituição à qual a Autoridade Policial pertença (Polícia Civil ou Federal). ${ }^{37}$

Embora com um viés mitigado em relação ao princípio do Juiz natural, resta claro que o princípio do Delegado de Polícia natural, também impede intromissões indevidas na atuação da Autoridade Policial na condução da investigação criminal, que só lhe pode ser retirada por motivos concretamente legítimos e justificados.

3ํ) Contraditório: como direito fundamental, não deve sofrer interpretação restritiva, advindo a obrigação de se garantir ao investigado um contraditório possível, com acesso à informação sobre a imputação e sobre os elementos coligidos, e a faculdade de se manifestar e apresentar argumentos que lhe sejam interessantes e favoráveis.

$4^{\underline{o})}$ Defesa: expresso na reação à imputação ampla no inquérito policial, que se manifesta por uma série de direitos que devem ser assegurados ao investigado, como o direito de ter ciência e de ser ouvido sobre a imputação, de ter conhecimento das investigações, de realizar ou requerer diligências ${ }^{38}$, mediante leitura garantista decorrente da hermenêutica evolutiva do artigo 14 do CPP, adiante comentado.

37 Nesse sentido encontra-se a Súmula no 11, do I Seminário Integrado da Polícia Judiciária da União e do Estado de São Paulo-Repercussões da Lei 12.830/13 na Investigação Criminal: “O ato administrativo que determina a avocação de inquérito policial, ou de outro procedimento análogo previsto em lei, reclama, como pressuposto de validade dos atos investigatórios subsequentes, circunstanciada motivação que, necessariamente, deverá estar relacionada à indevida condução da investigação, suficientemente demonstrada".

38 FERNANDES, Antônio Scarance. Reação defensiva à imputação. São Paulo: RT, 2002, p.130. 
$\left.5^{\circ}\right)$ Publicidade: a publicidade deve ser tratada como regra no inquérito policial, sendo, contudo, restringível, com o sigilo admitido e direcionado sobretudo para a preservação de direitos individuais e apenas remotamente para a proteção da eficiência dos atos investigatórios.

6ำ) Paridade de armas: viabilizar a oportunidade de manifestação e argumentação tanto da acusação quanto e sobretudo da defesa, de modo a buscar um equilíbrio de forças já na etapa de investigação preliminar.

$7^{\circ}$ ) Imparcialidade: consoante já antecipado, a autoridade investigante deve postar-se em posição equidistante dos que se converterão, na eventual etapa judicial da persecução, nos polos adversos de acusação e de defesa. Não deve o Estado-investigador laborar com olhos e ouvidos cingidos unicamente aos imperativos acusadores.

$8^{\circ}$ ) Reserva de jurisdição: exigência de formulação de representações para a avaliação e decretação de provimentos cautelares limitadores de direitos individuais exclusivos do Poder Judiciário com exposição fundamentada quanto à necessidade de cada medida.

9) Inadmissibilidade das provas ilícitas: tratando-se de investigação preliminar eivada de nulidades, conduzida com ferimentos a direitos individuais, dela derivarão consequentemente provas imprestáveis.

$10^{\circ}$ ) Duração razoável da investigação: o inquérito policial é temporário e a investigação preliminar deve ser concluída em prazo razoável, com celeridade.

11º) Presunção de não culpa: aplicação das normas de tratamento e de juízo extraídas da presunção de não culpa também na etapa extrajudicial da persecução. 
$12^{\circ}$ ) Não autoincriminação: a investigação preliminar, com maior intensidade até que no processo judicial, precisa atender todas as implicações decorrentes do princípio da não autoincriminação, para o reto e íntegro respeito às garantias fundamentais e ao direito de defesa dos sujeitos investigados.

Adota-se na investigação criminal, portanto, um contraditório possível, ainda que mitigado quando comparado com a sua plenitude no processo judicial, porém com uma participação cada vez mais ativa da defesa na etapa extrajudicial, na busca de uma igualdade de condições com a acusação, visto que esta requisita instauração de inquérito policial e diligências investigativas e acompanha o procedimento regular e oficialmente, seja nos pedidos de dilação de prazos e em todas as representações formuladas, seja após a conclusão da apuração, objetivando com isso uma paridade de armas dos sujeitos processuais, para também melhor antecipar a produção de legítimos elementos probatórios que favoreçam o investigado, inclusive para demonstrar sua inocência ou amenizar sua responsabilidade penal.

\section{INQUISITIVIDADE E INQUISITORIEDADE}

Para o bom entendimento do exercício do direito de defesa na investigação criminal, é preciso notar que a denominada característica da "inquisitividade" do inquérito policial não deve ser confundida com a terminologia "inquisitória" ou "inquisitorieda$\mathrm{de}^{\prime \prime}$, porquanto esta possui origem histórica e se relaciona com o autoritário período da justiça eclesiástica, cujo último resquício no direito processual penal brasileiro residia no antigo "processo judicialiforme" 39 , que misturava a fase extrajudicial com a judicial numa mesma autoridade pública, a qual investigava, acusava e julgava.

39 Tal procedimento estava consignado na Lei no $4.611 / 65$ e no capítulo V, do título II, do livro II do Código de Processo Penal (que contou com revogação e alteração legislativa expressa na Lei no $11.719 / 08)$. 
Nesse sentido, assim ensina Marta Saad: ${ }^{40}$

O modelo inquisitório, portanto, não permitia qualquer ingerência do interessado no procedimento, acumulando o inquisidor as funções de acusar, defender e julgar. Nesse cenário, nada podia o acusado.

De forma diferente, o poder-dever inquisitivo não afasta a participação dos interessados, acusado ou ofendido. Ao contrário, os esforços se somam, trabalhando juntos na busca da verdade.

Assim, a característica "inquisitiva" do inquérito policial deve ser entendida como imprescindível para uma investigação eficiente, amparada na independência funcional da autoridade presidente da apuração preliminar, que referendará a atuação endógena da defesa na investigação por meio da aplicação de um contraditório possível. Ou seja, a inquisitividade do inquérito policial revela em sua substancia a efetivação garantista e democrática da investigação criminal.

Com efeito, é preciso compreender a inquisitividade no âmbito de um Estado Democrático de Direito, integrada ao devido processo legal, de modo a abranger também a etapa extrajudicial da persecução penal.

Na fase preliminar e extrajudicial de investigação criminal, sob presidência do Delegado de Polícia, a ordem jurídica dispõe que a formalização e materialização dos atos sejam circunscritos no inquérito policial (ou em outro procedimento investigatório previsto em lei como o termo circunstanciado), que contará com um caráter inquisitivo-garantista, para de um lado viabilizar a dinâmica necessária que uma apuração preliminar exige, porém sem deixar de atender aos direitos e garantias fundamentais do sujeito submetido à persecução penal, inclusive, e sobretudo, a ele assegurando o exercício de sua defesa.

40 SAAD, Marta. O direito de defesa no inquérito policial. São Paulo: Editora Revista dos Tribunais, 2004, p.156-157. 
Portanto, a "inquisitividade" reconhecida ao inquérito policial não pode ser retratada numa visão estática da classificação tradicional dos sistemas processuais, que os cataloga como sendo "inquisitórios", acusatórios ou mistos ${ }^{41}$, equívoco que ainda hoje leva parte da doutrina processualista penal a entender de maneira irrefletida e incorreta que o investigado não pode ter nenhuma participação na primeira etapa da persecução criminal brasileira. ${ }^{42}$

De um modo geral, no originário e superado modelo "inquisitório" as funções de investigar, acusar, defender e julgar se encontravam acumuladas numa mesma pessoa ou autoridade pública, o que dificultava ou mesmo inviabilizava que o sujeito a quem o fato era imputado se manifestasse de maneira relevante, e tornava na prática inexistente o exercício de sua defesa.

A inquisitividade na fase extrajudicial, por outro lado, se faz necessária para que o inquérito policial atinja sua finalidade de coligir elementos para a reta apuração dos fatos, servindo de um lado e precipuamente como um filtro garantista, evitando ações penais precipitadas e sem justa causa e, de outra banda,

41 Importante notar que, na prática, não existe país que adote um sistema acusatório ou inquisitório "puro", pois todos os sistemas criminais são produto de intercâmbios de diferentes tradições legais, como o sistema presente nos países de origem anglosaxônica da common law (como a Inglaterra e os Estados Unidos da América), marcado pela característica adversarial (que não é pura e propriamente acusatório), e o sistema nos países de origem romano-germânica da civil law, observado nos países da Europa continental e da América Latina, que por sua vez apresentam muito mais características acusatórias que aquelas típicas do sistema inquisitório "puro", concentrador das funções de investigação, acusação e decisão criminal numa mesma autoridade. O denominado sistema "inquisitório" até hoje carrega forte conotação negativa decorrente das arbitrariedades e do emprego de torturas durante a "Santa Inquisição" promovida pela Igreja Católica, iniciada no século XIII para acabar com as "grandes heresias" na Europa (especialmente no sul da França), e que atingiu seu pico na Espanha no final do século XV, e não representa os sistemas criminais contemporâneos que muitos sustentam equivocadamente serem "inquisitórios". Nesse sentido: BULNES, Mar Jimeno. American criminal procedure in european context. Cardozo j. of international Law and Comparative Law, 2013, p.409-445.

42 SAAD, Marta. O direito de defesa no inquérito policial. São Paulo: Editora Revista dos Tribunais, 2004, p.155. 
como um instrumento para obtenção de subsídios que propiciem um avanço regular da persecução criminal em juízo.

Destarte, a característica da inquisitividade (e não "inquisitoriedade") não pode receber uma equivocada interpretação como sinônimo de arbitrariedade ou autoritarismo na condução da investigação criminal. Ao reverso, o Delegado de Polícia deve atuar de modo imparcial, e não de maneira a satisfazer interesses próprios no comando da apuração preliminar, e muito menos se pautando única, cega e meramente por teses de acusação ou de defesa, sob pena de responsabilização criminal e funcional. Deve a Autoridade Policial esgotar as hipóteses investigativas cabíveis e as circunstâncias fáticas por meio da obtenção de todos os elementos probatórios que a lei admita obter, independente de serem favoráveis ou prejudiciais à pessoa do investigado.

Dessa feita, a inquisitividade do inquérito policial deve ser vista e deflagrada de maneira positiva, associada à independência funcional (discricionariedade técnico-jurídica motivada) quando da tomada de decisões nos atos legais de polícia judiciária, por meio de escorreita fundamentação dos despachos decisórios na direção e na formalização da investigação criminal, e submetida a constante controle judicial, bem como suscetível a atuante fiscalização e manifestação da defesa e da acusação.

Como já registrado, o caráter inquisitivo do inquérito policial, até então sustentado doutrinariamente pela suposta ausência de ampla defesa e contraditório, sofreu intensa mitigação, precisamente para se integrar aos princípios da Constituição Federal de 1988, convertendo o procedimento em um filtro garantista apurativo da verdade legalmente atingível dos fatos, ou seja, daquilo que efetivamente ocorreu dentro do que for possível elucidar nos limites da lei, e admitindo a participação dos envolvidos, mormente do sujeito investigado, por intermédio de um contraditório possível no procedimento investigatório legal. 


\section{Publicidade e Sigilo do inQuérito policial}

No atual estágio de afirmação do Estado Democrático de Direito, a regra para a atuação estatal é a da publicidade, por exigência expressa da Carta Magna, que no inciso LX de seu artigo

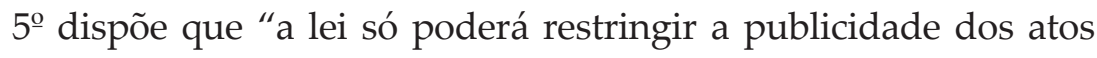
processuais quando a defesa da intimidade ou o interesse social o exigirem", e no caput de seu artigo 37 elenca o princípio da publicidade como norte de obediência por toda a Administração Pública.

Sendo assim, necessário se faz reler a característica do inquérito policial que, na doutrina mais tradicional e conservadora, sem maiores reflexões, costuma ser considerado em regra um "procedimento sigiloso", com base na redação do artigo 20, caput, do Código de Processo Penal: "A autoridade assegurará no inquérito o sigilo necessário à elucidação do fato ou exigido pelo interesse da sociedade".

Hodiernamente, para a adequação deste instrumento de formalização da investigação criminal, à luz da garantia e do princípio da publicidade imposto para todo o Poder Público, comando escancarado na Constituição Federal em seu citado artigo 37, mister se faz reconhecer o inquérito policial como sendo um procedimento de publicidade restringível, e não sigiloso como regra.

Nesse sentido é o escólio de Maurício Zanóide de Moraes $^{43}$, ao comentar a publicidade na fase preliminar investigativa da persecução penal:

Não poderá mais prevalecer a crença de que essa fase persecutória é em regra sigilosa, sendo a publicidade sua exceção. Isso porque, por força do já citado caput do art. 37 da Cons-

43 MORAES, Maurício Zanóide de. Publicidade e proporcionalidade na persecução penal brasileira. In: ALMEIDA, José Raul Gavião de; FERNANDES, Antônio Scarance; MORAES, Maurício Zanóide de (Coord.). Sigilo no processo penal: eficiência e garantismo. São Paulo: Editora Revista dos Tribunais, 2008, p. 44. 
tituição, estar-se-ia descumprindo o que ela impõe quanto a que todo ato da Administração Pública (direta ou indireta) é, em regra, público.

Em sentido similar, Marcelo de Lima Lessa ${ }^{44}$ ensina que a literalidade do aludido artigo 20 do CPP já reforça que o sigilo deve ser interpretado como exceção:

Com efeito, preceitua o artigo 20 do Código de Processo Penal que "a autoridade assegurará no inquérito o sigilo necessário à elucidação do fato ou exigido pela sociedade". Note-se, o sigilo, conforme se depreende da própria essência do dispositivo, não se configura em regra, mas sim, em exceção, sendo tão somente admitido enquanto demonstrada a sua extrema e comprovada necessidade, ou ainda, no mesmo sentido, quando o interesse público vier a conclamá-lo. Diante disso, num primeiro momento, figura-se necessária a medida - sempre precedida de motivado despacho da Autoridade Policial - quando a deliberada difusão das providências a serem adotadas, vierem a de qualquer forma baldar a persecução desenvolvida pela polícia judiciária, dando ensejo a uma contra-atividade tendente a prejudicá-la através de fraudes, peitas ou coações, incluindo-se aí a própria evasão do investigado, no mais das vezes, inspirado em subtrair-se da ação da justiça ou da responsabilidade de reparar o dano por ele causado. Em segundo plano, busca ainda o sigilo evitar com que a repercussão causada por certas infrações penais, notadamente as de conotação excessivamente torpe (v.g., crimes contra a liberdade sexual), choquem a serenidade pública.

Dessa forma, em sendo a publicidade a regra nos atos persecutórios, tanto investigativos quanto processuais (neles abrangidos o inquérito policial evidentemente), há de se reconhecer que qualquer pessoa pode ter acesso aos autos do procedimento investigatório, como regra. Contudo, por se tratar de mecanismo que resvala diretamente em direitos

44 LESSA, Marcelo de Lima. O sigilo na fase inquisitiva. São Paulo: Informativo Adpesp - Associação dos Delegados de Polícia do Estado de São Paulo, 2004. 
fundamentais como da intimidade, há possibilidade de se restringir motivadamente essa publicidade (sigilo externo ou publicidade interna).

Logo, conquanto a regra seja a publicidade, esta é restringível em sede de investigação criminal, e o desafio consiste em justamente se definir parâmetros legítimos para a decretação do sigilo externo (ou publicidade restrita) ou mesmo do ainda mais excepcional sigilo interno.

Sob um constitucional enfoque garantista, o sigilo dos autos do inquérito policial poderá se fazer necessário acima de tudo para evitar violações a direitos fundamentais, em especial a privacidade, a intimidade e a imagem das partes envolvidas na investigação criminal em curso, em homenagem ao inciso $X$, do artigo $5^{\circ}$, da Carta Magna. ${ }^{45}$

Nesse ponto, oportuna a reprodução da lição de Édson Luis Báldan: ${ }^{46}$

A cláusula de sigilo (CPP, art. 20), que pode ser decretada pela própria Autoridade Policial ou pelo Juiz de Direito, antes que ferramenta de eficiência da investigação, é providência que configura, em última instância, prestígio à presunção constitucional de não-culpabilidade e da intimidade da pessoa investigada (nos termos da CRFB, art. $5^{\circ}, X, V, X I, X I I I$ e LX, e do CPP, art. 792, § $1^{\circ}$ ). Decreta-se o sigilo não para lançar trevas sobre o caminho da investigação e, assim, impedir o imputado de esquadrinha-lo à cata de sua defesa. Baixa-se o segredo para que os holofotes da imprensa (nem sempre cônscia) não avassalem

$45 \mathrm{CF}$, art. 5ㅇ, X: "são invioláveis a intimidade, a vida privada, a honra e a imagem das pessoas, assegurado o direito a indenização pelo dano material ou moral decorrente de sua violação".

46 BALDAN, Édson Luis. Devida investigação legal como derivação do devido processo legal e como garantia fundamental do imputado. In: KHALED JR., Salah (Coord.). Sistema penal e poder punitivo: estudos em homenagem ao prof. Aury Lopes Jr. Florianópolis: Empório do Direito, 2015, p.173. 
direitos individuais manejados nos autos. Remotamente protege-se a eficiência dos atos investigatórios cuja revelação poderia ser-lhe nociva.

Percebe-se que a restrição à regra da publicidade deve se operar por determinação fundamentada do Delegado de Polícia presidente do procedimento investigatório, conforme inteligência que se depreende da combinação dos citados artigos $5^{\circ}$ inciso LX da Constituição Federal com o artigo 20 do Código de Processo Penal, ou então por expresso mandamento legal, como nos crimes sexuais, na forma do artigo 234-B do Código Penal, que determina que os processos (e por óbvio os correlatos procedimentos investigatórios) que apuram crimes contra a dignidade sexual correrão em "segredo de justiça", que corresponde ao "sigilo externo" conforme adiante explanado.

Nesse contexto, nada impede que os próprios sujeitos envolvidos (investigados ou vítimas) diretamente ou por meio de seus Advogados, pleiteiem à Autoridade Policial a decretação do sigilo externo dos autos do procedimento investigatório, visando evitar a publicidade abusiva e a exploração na divulgação leviana, inconsequente ou sensacionalista dos fatos pelos meios de comunicação de massa.

Do magistério de Gustavo Henrique Righi Badaró ${ }^{47}$, extrai-se que o "segredo de justiça" consiste na expressão como impropriamente é conhecida a denominada publicidade interna ou restrita, e entendida como sendo a limitação do acesso ao conteúdo somente às partes e seus Advogados (além das autoridades e agentes públicos atuantes no caso) e equivalente ao citado sigilo externo. Já a publicidade externa (também designada ampla, popular ou geral) seria a regra, de modo a considerar os autos acessíveis a todo cidadão.

47 BADARÓ, Gustavo Henrique Righi Ivahy. Processo penal. Rio de Janeiro: Elsevier, 2014, p. 27. 
Em resumo, vislumbram-se três níveis de graduação da limitação à publicidade dos autos, ou três níveis de intensidade do sigilo ao conteúdo dos procedimentos investigatórios legais:

$1^{\underline{o})}$ Publicidade externa: representa a regra geral, com acesso aos autos investigatórios a qualquer cidadão;

$\left.2^{\underline{o}}\right)$ Publicidade interna ou sigilo externo: segundo nível correspondente ao denominado "segredo de justiça", tornando os autos acessíveis apenas às partes diretamente interessadas e seus Advogados;

$3^{\text {o) }}$ Sigilo interno: terceiro e excepcional nível, afeto aos elementos relacionados a diligências em andamento e ainda não documentadas nos autos investigatórios principais, normalmente tramitando em autos apartados, com acesso restrito às autoridades e agentes públicos, por imprescindível prazo legal determinado, tema a ser aprofundado no tópico seguinte deste trabalho.

Portanto, o Delegado de Polícia pode decretar motivadamente o sigilo externo (segredo de justiça) no procedimento investigatório criminal, limitando o acesso aos autos às Autoridades (Policial e Judicial) e às partes, acusação (vítima nas infrações de ação penal privada ou Promotor nas ações públicas) e defesa (Advogado ou Defensor Público) e, de igual modo, poderá decretar o sigilo interno, nos elementos relacionados a diligências em andamento ainda não documentadas nos autos principais, somente quando houver risco de comprometimento da eficiência, da eficácia ou da finalidade das diligências. ${ }^{48}$

48 Consoante $\S 11$ do artigo $7^{\circ}$ do Estatuto da OAB, com o texto dado pela Lei nํㅜ 13.245/16: “No caso previsto no inciso XIV, a autoridade competente poderá delimitar o acesso do advogado aos elementos de prova relacionados a diligências em andamento e ainda não documentados nos autos, quando houver risco de comprometimento da eficiência, eficácia ou da finalidade das diligências". 
Com efeito, observa-se que uma leitura constitucional impõe que o inquérito policial deve ser considerado como procedimento de publicidade restringível (e não mais sigiloso como regra), tratando-se sua limitação via sigilo como exceção (tanto o sigilo externo quanto e especialmente o sigilo interno). Uma vez decretado o sigilo externo nos autos do procedimento investigatório, a lei reconhece a exigência de procuração para o acesso aos autos pelo Advogado. ${ }^{49}$

\section{EXercício EXógeno E ENDógeno DA DEFESA NO INQUÉRITO POLICIAL}

O direito de assistência advocatícia em sede de investigação criminal pode ser exercido por medidas externas, fora dos autos do procedimento investigatório (exercício exógeno), em regra determinadas pela Autoridade Judicial competente, e também por providências pleiteadas internamente (exercício endógeno), nos próprios autos de inquérito policial.

Nesse sentido oportuno o escólio de Marta Saad: ${ }^{50}$

Conforme o direito de defesa se exerça internamente, nos próprios autos de inquérito policial, por meio do interrogatório ou de solicitações de diligências ao Delegado de Polícia, ou externamente, fora dos autos, pode o exercício do direito de defesa ser classificado como endógeno e exógeno ao inquérito policial. Não há dificuldade, na doutrina, em aceitar e reconhecer o exercício exógeno do direito de defesa, que pode ser concretizado por meio do habeas corpus, mandado de segurança, por requerimento endereçado ao Promotor Público ou por petição dirigida ao Juiz de Direito, solicitando o relaxa-

49 Estatuto da $\mathrm{OAB}$, art. 7으, §10, com a redação dada pela Lei ํo 13.245/16: "nos autos sujeitos a sigilo, deve o advogado apresentar procuração para o exercício dos direitos de que trata o inciso XIV".

50 SAAD, Marta.O direito de defesa no inquérito policial. São Paulo: Revista dos tribunais, 2004, p. 270-271. 
mento da prisão em flagrante, liberdade provisória, restituição de bens apreendidos ou até a busca de seu juiz natural. (...) Contudo, para que haja efetivo exercício da defesa, tal qual assegurado no art. 5, LV da Constituição da República, não basta o reconhecimento do exercício exógeno do direito de defesa, mas há de se praticar de forma endógena o exercício do direito de defesa, no curso do inquérito policial, na própria delegacia de polícia, para além do preceito já existente (art. 14 do (PP), por meio de mecanismos apropriados.

O exercício endógeno consagra o ponto de atuação direta da defesa técnica na etapa extrajudicial da persecução penal, principalmente na apresentação de razões e quesitos que serão levados em consideração pela Autoridade Policial presidente da apuração, e contribui para a aproximação da verdade atingível dos fatos investigados.

Desse modo, ganha a investigação criminal não só maior credibilidade na formalização dos atos de polícia judiciária com o reforço e a vinculação da defesa técnica da pessoa investigada, como também possibilita a edificante aplicação de contraditório na fase extrajudicial, que certamente influi na instrução judicial e na avaliação dos elementos amealhados na apuração penal preliminar.

\section{EXAME DE AUTOS INVESTIGATÓRIOS}

O inciso XIV do artigo $7^{\circ}$ do Estatuto da OAB (Lei Federal nº 8.906/1994), alterado pela recente Lei Federal no $n^{\text {o }}$ 13.245/2016, assim dispõe:

São direitos do advogado:

(...)

XIV - examinar, em qualquer instituição responsável por conduzir investigação, mesmo sem procuração, autos de flagrante e de investigações de qualquer natureza, findos ou em 
andamento, ainda que conclusos à autoridade, podendo copiar peças e tomar apontamentos, em meio físico ou digital.

Em confronto com o texto anterior do dispositivo ${ }^{51}$, notase de pronto que houve uma ampliação dos órgãos expressamente compelidos a facultar o acesso aos autos, antes previsto apenas para as repartições policiais, e agora para qualquer instituição responsável por conduzir investigação, demonstrando assim a vontade do legislador em viabilizar ao defensor examinar os autos de procedimentos investigatórios em qualquer instituição pública, sejam os órgãos públicos tradicional, explícita e legitimamente incumbidos da apuração das infrações penais comuns (Polícias Civis e Polícia Federal), seja um órgão ministerial para aqueles que argumentam que a acusação pública pode conduzir diretamente investigações penais, seja qualquer outro ente estatal com função investigatória para a apuração de quaisquer tipos de infrações (Polícias Militares para investigações de delitos da Justiça Castrense e Tribunais de Justiça para apuração de infrações de agentes públicos com prerrogativa de função como, por exemplo, Prefeitos e Juízes de Direito).

Vale lembrar que, antes da publicação de referida Lei $\mathrm{n}^{\mathrm{o}}$ 13.245/2016, o Conselho Nacional do Ministério Público editou uma resolução (norma infralegal), sob número 13, datada de 02 de outubro de 2006, com o propósito de instituir e disciplinar um procedimento investigatório criminal pelo órgão público acusador, a pretexto de regulamentar o artigo $8^{\circ}$ da Lei Complementar no 75/1993 (Estatuto do Ministério Público da União). Referida norma infralegal, em seu artigo 13, II, prevê que os atos e peças do procedimento investigatório criminal são públicos e tal publicidade consistirá no deferimento do pedido de vista ou extração de cópias desde que o Advogado tenha "procuração com poderes específicos".

51 Antiga redação do aludido inciso XIV: "examinar em qualquer repartição policial, mesmo sem procuração, autos de flagrante e de inquérito, findos ou em andamento, ainda que conclusos à autoridade, podendo copiar peças e tomar apontamentos". 
Diante da alteração promovida pela Lei $n^{-0}$ 13.245/2016, vislumbra-se a derrogação do trecho do citado dispositivo da resolução, na medida em que a nova redação do artigo $7^{\circ}$, inciso XIV do Estatuto da OAB ampliou o exame pelo defensor de autos de investigação de qualquer natureza, mesmo sem procuração, incluindo, por óbvio, o aludido procedimento investigatório criminal do órgão ministerial. ${ }^{52}$

Percebe-se que a alteração do Estatuto da OAB pela Lei no 13.245/2016 teve como uma de suas finalidades a busca de um equilíbrio entre a acusação e a defesa, objetivando um ideal de paridade de armas das partes processuais, na medida em que, se ao acusador é reconhecida a efetiva participação ativa na etapa extrajudicial de investigação criminal, o mesmo deve valer para o defensor, mormente tendo em vista que os órgãos públicos de acusação têm intentado promover a investigação criminal direta e unilateralmente.

Ademais, o texto legal impõe o acesso do Advogado a "investigações de qualquer natureza", vale dizer, não compreende apenas o inquérito policial de delitos comuns (da Polícia Civil e Federal), o inquérito policial militar, os polêmicos procedimentos investigatórios criminais de órgãos ministeriais, os termos circunstanciados e quaisquer outras investigações de natureza criminal. ${ }^{53}$ Também abrange toda espécie de investigação, ainda que não criminal, como processos administrativos, sindicâncias, apurações preliminares, inquéritos civis públicos, uma apuração administrativa levada a efeito contra alguém por qualquer órgão como, por exemplo, na seara financeira, o COAF. ${ }^{54}$ Trata-se de

52 CAVALCANTE, Márcio André Lopes. Comentários à Lei 13.245/2016, que assegura a participação do advogado no interrogatório e nos depoimentos realizados na investigação criminal. Portal Dizer o Direito, 13 jan. 2016.

53 CABETTE, Eduardo Luiz Santos. Primeiros comentários à Lei 13.245/16 que altera o Estatuto da $\mathrm{OAB}$ e regras da investigação criminal. Revista Jus Navigandi, Teresina, fev. 2016.

54 A sigla COAF significa "Conselho de Controle de Atividades Financeiras". Trata-se de 
um texto legal amplo, claro e evidente, e não mais de uma redação literalmente restritiva, que já reclamava ampliação numa interpretação sistemática e extensiva.

Como se observa ainda, as modificações promovidas pela Lei Federal no 13.245/2016, em sua essência, não alteraram a atuação do direito de defesa nos procedimentos sob presidência das instituições públicas de polícia judiciária, as quais, tanto por lei quanto na esfera jurisprudencial, como na Súmula Vinculante n⿳o $14^{55}$, já reconheciam a participação do defensor na investigação penal, fato que foi sedimentado pela novel legislação.

\section{AssistênCia Advocatícia, APresentação de pedidos, RAZÕES E QUESITOS}

O inciso XXI do artigo $7^{\circ}$ do Estatuto da OAB, cuja redação foi introduzida pela citada Lei Federal no 13.245/2016, prevê que na assistência prestada a seus clientes investigados, o defensor pode apresentar razões e quesitos no curso da apuração criminal extrajudicial, in verbis:

Art. 7ํ. São direitos do advogado:

XXI - assistir a seus clientes investigados durante a apuração de infrações, sob pena de nulidade absoluta do respectivo interrogatório ou depoimento e, subsequentemente, de todos os elementos investigatórios e probatórios dele decorrentes ou derivados, direta ou indiretamente, podendo, inclusive, no curso da respectiva apuração:

a) Apresentar razões e quesitos.

uma entidade do Ministério da Fazenda, criada como uma Unidade de Inteligência Financeira (UIF) que atua na prevenção dos crimes de lavagem de dinheiro, instituída pela Lei Federal no 9.613/1998.

55 STF, Súmula vinculante $n^{\circ}$ 14, de 09.02.2009: “É direito do defensor, no interesse do representado, ter acesso amplo aos elementos de prova que, já documentados em procedimento investigatório realizado por órgão com competência de polícia judiciária, digam respeito ao exercício do direito de defesa". 
Trata-se de salutar inovação legislativa que reforça a devida atuação da defesa na investigação criminal, e que deve ser conjugada com o artigo 14 do CPP que permite ao investigado requerer qualquer diligência à Autoridade Poli$\operatorname{cial}^{56}$, compatível com a manifestação da paridade de armas na etapa preliminar da persecução penal, que não se esgota no conhecimento do conteúdo do procedimento investigatório por parte do investigado e de seu defensor, na medida em que apresenta também seu lado militante, consubstanciado em um conhecimento ativo ${ }^{57}$, vale dizer, naquilo que é levado ao conhecimento por parte do imputado aos autos da investigação criminal. ${ }^{58}$

Nesse sentido, a defesa pode e deve oferecer à autoridade presidente da investigação criminal argumentos e razões fáticas e jurídicas, requerer diligências investigatórias, pleitear quesitos para exames periciais (CPP, art.176), juntar documentos físicos ou digitais, apresentar pareceres técnicos e formular quaisquer outras providências legais, as quais serão submetidas à avaliação do Delegado de Polícia, que deve indeferir somente quando fundamentadamente as considerar ilegais, ou, de maneira excepcional e concreta, irrelevantes, impertinentes ou protelatórias, aplicando por analogia a disciplina da instrução judicial (CPP, art. 400, $\S 1^{\circ}$ ).

56 Quanto ao tema, destaca-se também a redação do artigo 184 do CPP que diz: "Salvo o caso de exame de corpo de delito, o Juiz ou a Autoridade Policial negará a perícia requerida pelas partes, quando não for necessária ao esclarecimento da verdade".

57 VIEIRA, Renato Stanziola. Paridade de armas no processo penal - vol. 02. Brasília: Gazeta Jurídica, 2014, p. 257.

58 Nesse contexto, Diogo Malan (2012, p. 304-305) e Renato Stanziola Vieira (2014, p. 263-264) entendem ser necessária a regulamentação de uma investigação defensiva no ordenamento brasileiro, de modo que o defensor (público ou particular) possa direta e legitimamente realizar diligências investigatórias que atendam aos interesses da pessoa investigada. 


\section{INDICIAMENTO E PRISÃO EM FLAGRANTE DELITO}

Como já adiantado, o inquérito policial compreende um procedimento extrajudicial de formalização das investigações criminais conduzidas pela polícia judiciária, presidido por Delegado de Polícia, de natureza formal administrativa e conteúdo material essencialmente jurídico ${ }^{59}$, destinado a apurar circunstâncias, autoria e materialidade delitiva como apoio à instrução judicial.

Destarte, no âmbito do inquérito policial, o instituto do indiciamento consiste no ato pelo qual o Delegado de Polícia manifesta sua convicção jurídica motivada ao imputar a uma pessoa a condição de provável autor ou partícipe da infração penal investigada no procedimento apurativo, e não deve ser confundido com o seu resultado e enfoque meramente formal, representado pelos atos dele decorrentes: a qualificação e interrogatório, as informações sobre a vida pregressa e a identificação do agente indiciado, com fundamento legal no artigo $6^{\circ}$ do Código de Processo Penal, respectivamente em seus incisos V, IX e VIII.

Oportuno notar que o indiciamento consubstancia ato privativo do Delegado de Polícia presidente da investigação criminal, pelo qual exara sua livre convicção jurídica motivada com independência funcional ${ }^{60}$, de acordo com amplo entendimento doutrinário e jurisprudencial expressamente sedimentado no artigo $2^{\circ}, \S 6^{\circ}$, da Lei Federal no 12.830/2013, abaixo reproduzido:

59 PITOMBO, Sérgio Marcos de Moraes. Inquérito policial: novas tendências. Belém: CEJUP, 1987, p.22.

60 De acordo com os citados comandos dos artigos 140, § $3^{\circ}$, da Constituição do Estado de São Paulo, e de dispositivos de outras Cartas Estaduais, e artigo $1^{\mathrm{o}}$, $\S 2^{\mathrm{o}}$, da Lei Complementar Paulista no 1.152/2011, com a redação estipulada pela Lei Complementar Estadual no 1.249/2014. 
O indiciamento, privativo do Delegado de Polícia, dar-se-á por ato fundamentado, mediante análise técnico-jurídica do fato, que deverá indicar a autoria, materialidade e suas circunstâncias.

Nesse sentido já se pronunciou tanto o Egrégio Supremo Tribunal Federal, após o advento da destacada Lei Federal ${ }^{61}$, quanto o Superior Tribunal de Justiça, que adotou idêntica posição. ${ }^{62}$

Convém anotar que não há óbice de requisição judicial ou formulada pelo órgão acusador para a realização específica de algum dos citados atos formais que resultam do indiciamento, caso imprescindível ao oferecimento da inicial acusatória, mormente a identificação do agente (CPP, art. 6으, VIII), em homenagem ao artigo 16 do destacado diploma de rito criminal. ${ }^{63}$

61 STF, 2 ${ }^{\mathrm{a}}$ T. - HC no 115.015-SP, Rel. Teori Zavascki, j. 27.08.13, p. 12.09.2013: “DIREITO PROCESSUAL PENAL. CRIMES CONTRA ORDEM TRIBUTÁRIA. INDICIAMENTO PELO MAGISTRADO APÓS RECEBIMENTO DA DENÚNCIA. CONSTRANGIMENTO ILEGAL. 1. Sendo o ato de indiciamento de atribuição exclusiva da Autoridade Policial. não existe fundamento jurídico que autorize o magistrado, após receber a denúncia, requisitar ao Delegado de Polícia o indiciamento de determinada pessoa. A rigor, a requisição dessa natureza é incompatível com o sistema acusatório, que impõe a separação orgânica das funções concernentes à persecução penal, de modo a impedir que o Juiz adote qualquer postura inerente à função investigatória. Doutrina. Lei 12.830/2013. 2. Ordem concedida".

62 STJ, RHC no 47.984-SP, Rel. Min. Jorge Mussi, julgado em 04.11.2014: “DIREITO PROCESSUAL PENAL. INDICIAMENTO COMO ATRIBUIÇÃO EXCLUSIVA DA AUTORIDADE POLICIAL.

O Magistrado não pode requisitar o indiciamento em investigação criminal. Isso porque o indiciamento constitui atribuição exclusiva da Autoridade Policial. De fato, é por meio do indiciamento que a Autoridade Policial aponta determinada pessoa como a autora do ilícito em apuração. Por se tratar de medida ínsita à fase investigatória, por meio da qual o Delegado de Polícia externa o seu convencimento jurídico sobre a autoria dos fatos apurados, não se admite que seja requerida ou determinada pelo Magistrado, já que tal procedimento obrigaria o presidente do inquérito à conclusão de que determinado indivíduo seria o responsável pela prática criminosa, em nítida violação ao sistema acusatório adotado pelo ordenamento jurídico pátrio. Nesse mesmo sentido, é a inteligência do art. $2^{\circ}, \S 6^{\circ}$, da Lei $12.830 / 2013$, o qual consigna que o indiciamento é ato inserto na esfera de atribuições da polícia judiciária. Precedente citado do STF: HC 115.015-SP, Segunda Turma, DJe 11.09.2013".

$63 \mathrm{CPP}$, art. 16: “O Ministério Público não poderá requerer a devolução do inquérito à autoridade policial, senão para novas diligências, imprescindíveis ao oferecimento da denúncia". 
Até o momento do indiciamento, o sujeito é tratado como "investigado", ou seja, mero "suspeito" ou, apenas, como uma parte envolvida não definida. Formalizado o ato, o indivíduo passa a ser designado "indiciado" e, na concepção técnico-jurídica justificada da Autoridade presidente do inquérito policial, figura como "provável autor" do fato objeto da investigação criminal. Trata-se, pois, da transposição de um juízo de possibilidade (mera suspeita) para outro de probabilidade (fundada suspeita).

Destaca-se que, nos casos de prisão em flagrante delito, o auto prisional substitui e equivale ao despacho de indiciamento, razão pela qual a "fundada suspeita" imposta pela lei processual para decretar a custódia provisória em flagrância (CPP, art. 304, § $1^{\circ}$ ) demanda também regular deliberação motivada, e implica da mesma maneira no formal indiciamento do sujeito, encerrando um juízo de probabilidade calcado no convencimento pela análise técnico-jurídica do fato, desenvolvido nos mesmos moldes e com idêntico raciocínio ao do indiciamento exarado no curso de procedimento investigatório iniciado via portaria, conquanto realizado em sede de cognição sumaríssima, pelo qual o indivíduo preso e autuado em flagrante delito passa a figurar como o "provável autor" da infração penal perscrutada. ${ }^{64}$

Em relação ao direito de defesa, importa registrar que tanto no interrogatório, oitiva do indiciado no âmbito do indiciamento, quanto em qualquer oitiva prestada por pessoa investigada no bojo de uma apuração criminal, está a Autoridade responsável obrigada a oportunizar assistência advocatícia ao sujeito, nos termos do acima destacado artigo $7^{\circ}$, inciso XXI, do Estatuto da OAB.

64 Como anotado, o indiciamento pode ocorrer tanto no curso do inquérito policial inaugurado via portaria quanto no momento da deliberação do Delegado de Polícia pela prisão em flagrante delito, ocasião em que o respectivo auto prisional ensejará o formal indiciamento. 
De igual sorte, o também mencionado inciso XIV do artigo $7^{\circ}$ do Estatuto da $\mathrm{OAB}^{65}$ reforça a prerrogativa do defensor em examinar autos de prisão em flagrante delito e de procedimentos investigatórios de maneira geral (sejam inquéritos policiais instaurados via portaria ou auto prisional ou mesmo termos circunstanciados e boletins de ocorrência).

Nesse contexto, propiciar a participação da defesa (tanto da autodefesa quanto da defesa técnica) durante a formalização da prisão em flagrante delito se revela de extrema importância, tendo em vista o rol de direitos e garantias a serem observados à pessoa presa, dentre os quais se destacam o respeito à dignidade, à integridade física e à moral (CF, art.5ํ, XLIX), o direito de permanecer calado e não produzir prova contra si (princípio da não autoincriminação - CF, art. 5으, LXIII e CADH, art.8o, II, “g”), o direito de comunicação à família e ao Juiz competente (CF, art. 5, LXII), direito ao recebimento de nota de culpa constando o motivo da prisão e os responsáveis pela captura e interrogatório (CF, art. 5º, LXIV e CPP, art. 306, § 2º), o direito à fiança quando admitida (CF, art. 5o, LXVI), o direito à assistência jurídica por Advogado ou Defensor Público (CPP, art.306, § $1^{\circ}$ ) e, havendo Advogado, o direito à comunicação reservada, e finalmente o direito ora em comento de exame e participação no auto prisional e correlato inquérito policial (Lei 8.906/94 - Estatuto OAB, art. 7º, III e XIV combinado com a Súmula Vinculante n⿳0 14).

Prosseguindo, na deliberação pelo indiciamento, seja no auto de prisão em flagrante delito seja mediante despacho no curso do inquérito policial, o Delegado de Polícia aponta os elementos fáticos e jurídicos motivadores de seu convencimento

$65 \mathrm{EOAB}$, art. 70: “São direitos do advogado:

(...)

XIV - examinar, em qualquer instituição responsável por conduzir investigação, mesmo sem procuração, autos de flagrante e de investigações de qualquer natureza, findos ou em andamento, ainda que conclusos à autoridade, podendo copiar peças e tomar apontamentos, em meio físico ou digital". 
quanto à materialidade e autoria delitivas, assim como no que tange à classificação jurídica do fato apurado. ${ }^{66}$

Desse modo, na hipótese de prisão flagrancial, o instante do indiciamento (e a lavratura dos atos formais que o integram) coincide com a própria elaboração do respectivo auto prisional, o qual também desencadeia a instauração de inquérito policial, servindo como peça inaugural do procedimento investigatório criminal. ${ }^{67}$

Já o indiciamento durante o trâmite do inquérito policial, concretizado mediante despacho fundamentado, deverá ocorrer quando e se a Autoridade Policial vislumbrar que os elementos amealhados são suficientes para apontar a autoria da infração penal perscrutada a determinado sujeito investigado. Por essa razão, espera-se que o indiciamento, nesses casos, somente seja levado a efeito após a obtenção de lastro probatório mínimo que, consoante privativo juízo técnico-jurídico do Delegado de Polícia presidente da investigação criminal, permita conferir a condição de provável autor ou partícipe ao indivíduo, o qual deixa de ser "mero suspeito" na concepção da Autoridade Policial.

66 Nessa vereda, Juliana Rosa Gonçalves Mota (2013, p.36) ressalta a importância da fundamentação da convicção jurídica do Delegado de Polícia no auto prisional, havendo inclusive diretriz institucional da Polícia Civil Paulista, consoante comando do artigo 7º, da citada Portaria DGP no 18/1998: “Na lavratura do auto de prisão em flagrante, a Autoridade Policial fará constar, no instrumento flagrancial, de maneira minudente e destacada, a comunicação ao preso dos direitos que lhe são constitucionalmente assegurados e, ainda, se este compreendeu-lhes o significado e [...] se desejou exercê-los.

$\S 2^{\underline{0}}$ A tipificação da conduta inicialmente atribuída ao preso no auto de prisão em flagrante será objeto de fundamentação autônoma na respectiva peça flagrancial, expondo a Autoridade Policial as razões fáticas e jurídicas de seu convencimento.

$\S 3^{o}$ Na nota de culpa entregue ao preso, a Autoridade Policial descreverá a conduta incriminada e indicará o tipo penal infringido".

67 Com entendimento similar, de que o indiciamento deve ser promovido concomitantemente com a lavratura do auto de prisão em flagrante delito: ZANOTTI, Bruno Taufner. Delegado de Polícia em ação: teoria e prática no Estado Democrático de Direito. Juspodivm: Salvador, 2016, p.217. 
Por tal motivo, não é incomum na prática, sendo inclusive recomendável para o satisfatório rumo da persecução penal extrajudicial a depender da dinâmica com que os elementos probatórios sejam obtidos, que o sujeito investigado, antes do indiciamento, seja ouvido em declarações, ainda enquanto figurar como "parte" ou "mero suspeito", oportunidade em que poderá oferecer argumentos defensivos e versão que lhe seja favorável e que implique na realização de diligências investigatórias para cabal e justa apuração dos fatos e revelação da verdade. Tal providência prestigia o contraditório e sua dimensão substancial representada pela ampla defesa.

De fato, sobretudo nos inquéritos policiais instaurados via portaria, o ideal é que o sujeito investigado seja previamente ouvido, para só então decidir o Delegado de Polícia pelo indiciamento ou não, devendo a Autoridade Policial expor motivadamente caso delibere pelo indiciamento, de modo a permitir o exercício do direito de defesa antes da conclusão do procedimento investigatório. ${ }^{68}$

Nesse contexto, figura o indiciamento, enquanto atribuição formal e suporte positivo da culpa penal lato $s e n s u^{69}$, como o momento mais adequado para a incidência do contraditório na investigação criminal, na medida em que a Autoridade Policial encerra um juízo de probabilidade com relação à autoria delitiva, partindo-se do geral para o individual, quando a imputação de um fato ao agente torna-se melhor delineada, e assim o investigado passar a ter ciência e condições mais

68 LOPES JR, Aury Lopes; KLEIN, Roberta Coelho. O indiciamento e a Lei 12.830/2013: um avanço, mas não o suficiente. Boletim IBCCRIM - Instituto Brasileiro de Ciências Criminais. Ano 21, no 249, ago. 2013.

69 LANFREDI, Cristian Sant'Ana; LANFREDI, Cristiano Sant'Ana; LANFREDI, Luís Geraldo Sant'Ana. Do utilitarismo ao garantismo: brevíssimo enquadramento da persecução penal, da polícia judiciária e das prisões processuais no crime de homicídio. In: MARZAGÃO JUNIOR, Laerte Idalino (Coord.). Homicídio crime rei. São Paulo: Quartier Latin, 2009, p. 152. 
efetivas de reagir e se defender dos elementos e circunstâncias contra ele amealhados. ${ }^{70}$

Logo, numa abordagem constitucional, o instituto do indiciamento deve ser considerado acima de tudo como meio de defesa, vale dizer, como instrumento de exercício tanto do contraditório formal, expresso no direito de ciência e de participação no procedimento investigatório, quanto também do contraditório substancial, compreendido pela ampla defesa na oportunidade de influenciar no rumo da investigação criminal, formulando pedidos e apresentando versões, dados ou argumentos que sejam favoráveis à pessoa do indiciado.

Nessa linha, oportuna a lição da professora Marta Saad: ${ }^{71}$

Indispensável e necessário, portanto, desde quando reunida prova que aponte o suspeito como provável autor do delito, o indiciamento deve ser visto como um marco, a partir do qual uma série de deveres e direitos - notadamente o direito de defesa - pode e deve ser exercida.

Ressalta-se que, da mesma maneira que o Delegado de Polícia deve determinar que se proceda ao formal indiciamento quando entender que o sujeito investigado é o provável autor do fato delituoso perscrutado, deixará de deliberar pelo indiciamento quando vislumbrar circunstâncias que possam afastar a responsabilidade penal do suspeito, como a presença e o reconhecimento provisório de causas excludentes de ilicitude ou mesmo de culpabilidade, consignando tais situações por meio de manifestação fundamentada em histórico de boletim de ocorrên-

70 ARGACHOFF, Mauro; RESENDE, Maurício José Mendes; TOLEDO, Carlos José Paschoal de; GERALDO, Júlio César dos Santos. Investigação do homicídio à luz do Estado Democrático de Direito. In: MARZAGÃO JUNIOR, Laerte Idalino (Coord.). Homicídio crime rei. São Paulo: Quartier Latin, 2009, p. 52.

71 SAAD, Marta Cristina Cury. Indiciamento como ato fundamentado da autoridade policial. Boletim informativo IBRASPP - Instituto Brasileiro de Direito Processual Penal. Ano 03, no 05, 2013, p.20. 
cia circunstanciado (sobretudo em se tratando de possível estado flagrancial $)^{72}$, no curso do inquérito policial via despacho, ou ainda no corpo do relatório final do procedimento investigatório criminal, sempre adotando as demais providências legais que o caso prático reclamar.

A deliberação e a conviç̧ão jurídica da Autoridade Policial, conquanto não vinculem a Autoridade Judicial e tampouco a acusação ou a defesa, servirão de primordial diretriz para o prosseguimento (ou não) ou para o deslinde de eventual ação penal.

\section{IMPEDIMENTO DE ACESSO}

A alteração legislativa promovida no Estatuto da OAB (Lei Federal no 8.906/1994) pela Lei Federal no 13.245/2016, também incluiu o parágrafo 12 no artigo $7^{\circ}$, com o texto abaixo colacionado:

$\S 12$. A inobservância aos direitos estabelecidos no inciso $X I V$, o fornecimento incompleto de autos ou o fornecimento de autos em que houve a retirada de peças já incluídas no caderno investigativo implicará responsabilização criminal e funcional por abuso de autoridade do responsável que impedir o acesso do Advogado com o intuito de prejudicar o exercício da defesa, sem prejuízo do direito subjetivo do Advogado de requerer o acesso aos autos ao juiz competente.

72 Consigna-se nessa linha o entendimento consolidado na Súmula ํㅜ 6, do I Seminário Integrado da Polícia Judiciária da União e do Estado de São Paulo-Repercussões da Lei 12.830/13 na Investigação Criminal: “É lícito ao Delegado de Polícia reconhecer, no instante do indiciamento ou da deliberação quanto à subsistência da prisão-captura em flagrante delito, a incidência de eventual princípio constitucional penal acarretador da atipicidade material, da exclusão de antijuridicidade ou da inexigibilidade de conduta diversa". Nesse sentido lecionava Sérgio Marcos de Moraes Pitombo (1987, p.40), asseverando a ilegalidade do indiciamento quando da presença de excludentes de ilicitude ou de culpabilidade. 
Referido dispositivo estabeleceu que o impedimento injustificado (leia-se, com intuito de prejudicar o exercício de defesa) do Advogado quanto ao exame de autos de investigação criminal, bem como o fornecimento incompleto ou com peças faltantes, implicará na responsabilização criminal e funcional por abuso de autoridade do agente público.

A adequação típica penal para tal mandado legal de criminalização se encontra no artigo $3^{\underline{0}}$, “j” da Lei Federal $n^{\underline{o}}$ 4.898/1965, e dispõe constituir abuso de autoridade qualquer atentado "aos direitos e garantias legais assegurados ao exercício profissional".

Frisa-se que referida figura delitiva prevê sanção penal de multa, perda do cargo e inabilitação para o exercício de outra função pública por até três anos e ainda de detenção de dez dias a seis meses (Lei no 4.895/1965, art. 6º, § $3^{\circ}$ ), consubstanciando infração de menor potencial ofensivo, de competência do Juizado Especial Criminal (Lei no 9.099/1995, art. 61).

O Advogado cujo acesso aos autos de procedimentos investigatórios tenha sido deliberado e indevidamente restringido, poderá formular pedido ao Poder Judiciário, inclusive mediante impetração de mandado de segurança, considerando o direto líquido e certo ora insculpido no destacado dispositivo do Estatuto da OAB.

Prudente ressaltar que a conduta do agente que impedir o acesso do Advogado deverá ser dolosa e imbuída da "intenção de prejudicar o direito de defesa" (dolo específico), sem prejuízo de caracterização de infração penal diversa ou mesmo em concurso de crimes, levando-se em consideração as circunstâncias do caso concreto. 


\section{REFERÊNCIAS BibLIOGRÁficAS}

ALMEIDA, Joaquim Canuto Mendes. O direito de defesa no inquérito policial. Revista da Faculdade de Direito da Universidade de São Paulo, v. 52. São Paulo: USP, 1957, p. 80-115.

. Princípios fundamentais do processo penal. São Paulo:

Revista dos Tribunais, 1973.

ANGERAMI, Alberto e PENTEADO FILHO, Nestor Sampaio. Direito administrativo sistematizado. São Paulo: Método, 2008.

ARGACHOFF, Mauro; RESENDE, Maurício José Mendes; TOLEDO, Carlos José Paschoal de; GERALDO, Júlio César dos Santos. Investigação do homicídio à luz do Estado Democrático de Direito. In: MARZAGÃO JUNIOR, Laerte Idalino (Coord.). Homicídio crime rei. São Paulo: Quartier Latin, 2009.

BADARÓ, Gustavo Henrique Righi Ivahy. Processo penal. Rio de Janeiro: Elsevier, 2014.

BALDAN, Édson Luis. Devida investigação legal como derivação do devido processo legal e como garantia fundamental do imputado. In: KHALED JR., Salah (Coord.). Sistema penal e poder punitivo. Florianópolis: Empório do Direito, 2015, p.155-182.

; AZEVEDO, André Boiani e. A preservação do devido processo legal pela investigação defensiva. Revista Jus Navigandi, Teresina, ano 11, n. 1013, 10 abr. 2006. Disponível em: <https://jus.com.br/artigos/8220>. Acesso em: 24 mar. 2016.

BARBOSA, Emerson Silva. O devido processo penal e as garantias do contraditório e da ampla defesa no inquérito 
policial. Sistema penal \& violência. Revista Eletrônica da Faculdade de Direito da Pontifícia Universidade Católica do Rio Grande do Sul. Porto Alegre, 2011, p.74-88. Disponível em: <http://revistaseletronicas.pucrs.br/ojs/index.php/ sistemapenaleviolencia/article/view/7942>. Acesso em: 30 mar. 2016.

BARBOSA, Ruchester Marreiros. Delegado natural é princípio basilar da devida investigação criminal. Revista Consultor Jurídico, 6 out. 2015. Disponível em: <http://www.conjur. com.br/2015-out-06/academia-policia-delegado-naturalprincipio-basilar-investigacao-criminal>. Acesso em: 29 mar. 2016.

BULNES, Mar Jimeno. American criminal procedure in european context. Cardozo j. of international Law and Comparative Law, vol. 21:409: 2013, p.409-445.

CABETTE, Eduardo Luiz Santos. Primeiros comentários à Lei 13.245/16 que altera o Estatuto da OAB e regras da investigação criminal. Revista Jus Navigandi, Teresina, fev. 2016. Disponível em: <https://jus.com.br/artigos/45887>. Acesso em: 17 fev. 2016.

CABRAL, Bruno Fontenele; SOUZA, Rafael Pinto Marques. Manual prático de polícia judiciária. Salvador: Jus Podivm, 2013.

CASTRO, Henrique Hoffmann Monteiro de. Juízos de prognose e diagnose do delegado são essenciais na investigação. Revista Consultor Jurídico, São Paulo, 9 ago. 2016. Disponível em: <http://www.conjur.com.br/2016ago-09/academia-policia-juizos-prognose-diagnose-saoessenciais-investigacao>. Acesso em: 15 ago. 2016.

; SANNINI NETO, Francisco. Independência funcional é prerrogativa do delegado e garantia da sociedade. Revista Consultor Jurídico, 2 jun. 2016. Disponível em: 
$<$ http://www.conjur.com.br/2016-jun-02/independenciafuncional-prerrogativa-delegado>. Acesso em 02 jun. 2016.

CAVALCANTE, Márcio André Lopes. Comentários à Lei 13.245/2016, que assegura a participação do advogado no interrogatório e nos depoimentos realizados na investigação criminal. Portal Dizer o Direito, 13 jan. 2016. Disponível em: <http://www.dizerodireito.com.br/ search?q=lei+13.245>. Acesso em: 17 fev. 2016.

DESGUALDO, Marco Antonio. Recognição visuográfica e a lógica na investigação. São Paulo: Polícia Civil do Estado de São Paulo, 2006.

DIDIER JR., Fredie. Curso de direito processual civil. Salvador: Jus Podivm, 2012.

DEZEM, Guilherme Madeira. Curso de processo penal. São Paulo: Editora Revista dos Tribunais, 2015.

DI PIETRO, Maria Sylvia Zanella. Direito administrativo. São Paulo: Atlas, 2003.

FERNANDES, Antônio Scarance. Reação defensiva à imputação. São Paulo: Revista dos Tribunais, 2002. . Processo penal constitucional. São Paulo: Revista dos Tribunais, 2007. - Reflexões sobre as noções de eficiência e de garantismo no processo penal. In: ALMEIDA, José Raul Gavião de; FERNANDES, Antônio Scarance; MORAES, Maurício Zanóide de (Coord.). Sigilo no processo penal: eficiência e garantismo. São Paulo: Editora Revista dos Tribunais, 2008, p.9-28.

GOLDSCHMIDT, James. Principios generales del proceso: problemas jurídicos y políticos del proceso penal. vol. II. Buenos Aires: Ediciones Jurídicas Europa-América, 1961. 
KEEDY, Edwin. The preliminary investigation of crime in France. University of Pennsylvania Law Review, v. 88, n. 4, February, 1940, p. 385-424.

LANFREDI, Cristian Sant'Ana; LANFREDI, Cristiano Sant'Ana; LANFREDI, Luís Geraldo Sant'Ana. Do utilitarismo ao garantismo: brevíssimo enquadramento da persecução penal, da polícia judiciária e das prisões processuais no crime de homicídio. In: MARZAGÃO JUNIOR, Laerte Idalino (Coord.). Homicídio crime rei. São Paulo: Quartier Latin, 2009, p.147-156.

LESSA, Marcelo de Lima. A independência funcional do Delegado de Polícia paulista. São Paulo: Adpesp - Associação dos Delegados de Polícia do Estado de São Paulo, 2012. . O sigilo na fase inquisitiva. São Paulo: Informativo Adpesp - Associação dos Delegados de Polícia do Estado de São Paulo, 2004.

LOPES JR., Aury Lopes. Direito processual penal. São Paulo: Saraiva, 2015. . Lei 13.245/2016 não acabou com caráter "inquisitório" da investigação. Revista Consultor Jurídico, 29 jan. 2016. Disponível em: <http://www.conjur.com.br/2016-jan-29/ limite-penal-lei-132452016-nao-acabou-carater-caraterinquisitorio-investigacao>. Acesso em 11 set. 2016. ; KLEIN, Roberta Coelho. O indiciamento e a Lei 12.830/2013: um avanço, mas não o suficiente. Boletim IBCCRIM - Instituto Brasileiro de Ciências Criminais. Ano 21, no 249, ago.2013.

MACHADO, André Augusto Mendes. Investigação criminal defensiva. São Paulo: Revista dos Tribunais, 2010.

MACHADO, Leonardo Marcondes. Investigação preliminar: por uma política de redução de dor. In: KHALED JR., Salah 
(Coord.). Sistema penal e poder punitivo. Florianópolis: Empório do Direito, 2015, p.333-343.

. O amadorismo na investigação criminal cobra seu preço no jogo processual. Revista Consultor Jurídico, 26 jan. 2016. Disponível em: <http://www.conjur.com.br/2016-jan-26/ academia-policia-amadorismo-investigacao-cobra-precojogo-processual>. Acesso em 17 fev. 2016.

MALAN, Diogo Rudge. Investigação defensiva no processo penal. Revista Brasileira de Ciências Criminais - RBCCrim. Ano 20, no 96, maio-junho, 2012, p.279-309.

MARTINS, Ives Gandra da Silva. Prefácio. In: PEREIRA, Eliomar da Silva; DEZAN, Sandro Lucio (Coord.). Investigação criminal conduzida por Delegado de Polícia: comentários à Lei 12.830/2013. Curitiba: Juruá, 2013, p.1517.

MOLINARI, Francesca Maria. Il segreto investigativo. Milano: Giuffrè, 2003.

MORAES, Bismael Batista de. Direito e polícia: uma introdução à polícia judiciária. São Paulo: Revista dos Tribunais, 1986.

MORAES, Maurício Zanóide de. Presunção de inocência no processo penal brasileiro: análise de sua estrutura normativa para a elaboraçãoo legislativa e para a decisão judicial. Rio de Janeiro: Lumen Juris, 2010. . Publicidade e proporcionalidade na persecução penal brasileira. In: ALMEIDA, José Raul Gavião de; FERNANDES, Antônio Scarance; MORAES, Maurício Zanóide de (Coord.). Sigilo no processo penal: eficiência e garantismo. São Paulo: Editora Revista dos Tribunais, 2008, p. 29-55.

MOTA, Juliana Rosa Gonçalves. Crítica livre: o gongorismo forense que permeia os atos de polícia judiciária-necessidade ou 
preciosismo. 2013. 53 p. Monografia (Processo Seletivo de Professor de Redação Oficial) - Academia de Polícia “Dr. Coriolano Nogueira Cobra". São Paulo, 2013.

MOURA, Maria Tereza Rocha de Assis. A prova por indícios no processo penal. Rio de Janeiro: Lumen Juris, 2009.

NUCCI, Guilherme de Souza. Código de processo penal comentado. São Paulo: Revista dos Tribunais, 2013.

PITOMBO, Sérgio Marcos de Moraes. Inquérito policial: exercício do direito de defesa. Boletim IBCCRIM - Instituto Brasileiro de Ciências Criminais. Ano 7, Edição Especial, no 83, out.1999, p.14. . Inquérito policial: novas tendências. Belém: CEJUP, 1987.

QUEIROZ, David. Delegado de Polícia, o primeiro garantidor de direitos fundamentais! Mas quem garante os direitos do garantidor? Empório do Direito, 02 jul. 2015. Disponível em: <http://emporiododireito.com.br/ delegado-de-policia-o-primeiro-garantidor-dedireitos-fundamentais-mas-quem-garante-os-direitosdo-garantidor-por-david-queiroz/>. Acesso em: 29 ago. 2016.

ROVÉGNO, André. O inquérito policial e os princípios constitucionais do contraditório e da ampla defesa. Campinas: Bookseller, 2005.

SAAD, Marta. Indiciamento como ato fundamentado da autoridade policial. Boletim informativo IBRASPP - Instituto Brasileiro de Direito Processual Penal. Ano 03, no 05, p.1921, 2013.

. O direito de defesa no inquérito policial. São Paulo: Editora Revista dos Tribunais, 2004.

SABELLA, Walter Paulo. Independência funcional e ponderação de princípios. Revista Justitia, 2007. Disponível 
em: <http://www.revistajustitia.com.br/artigos/y58056. pdf $>$. Acesso em: 04 jul. 2016.

SOUZA, Diego Fajardo Maranha Leão de; LEITE, Rosimeire Ventura. O sigilo no processo criminal e o interesse público à informação. In: ALMEIDA, José Raul Gavião de; FERNANDES, Antônio Scarance; MORAES, Maurício Zanóide de (Coord.). Sigilo no processo penal: eficiência e garantismo. São Paulo: Editora Revista dos Tribunais, 2008, p.203-238.

TRINDADE, Daniel Messias da. O garantismo penal e a atividade de polícia judiciária. Porto Alegre: Núria Fabris, 2012.

VIEIRA, Renato Stanziola. Paridade de armas no processo penal vol. 02. Brasília: Gazeta Jurídica, 2014.

ZACCARIOTTO, José Pedro. A polícia judiciária no estado democrático. Sorocaba: Brazilian Books, 2005.

ZANOTTI, Bruno Taufner; SANTOS, Cleopas Isaías. Delegado de Polícia em ação: teoria e prática no Estado Democrático de Direito. Salvador: Juspodivm, 2016. 
A defesa no inquérito policial 